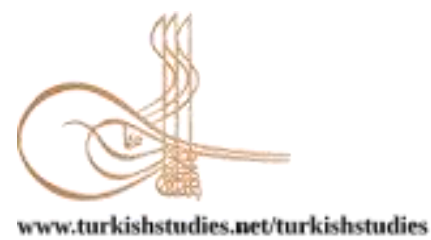

Turkish Studies

\title{
Yabancı Dil Olarak Türkçe Öğretiminde Kullanılan Ders Kitaplarının Uzaktan Öğretime Uygunluğu: Yeni İstanbul Örneği
}

\author{
The Appropriacy of Coursebooks Used to Teach Turkish as a Foreign Language for Distant \\ Education: The Example of New Istanbul Coursebook
}

\author{
Fatma Bölükbaş Kaya* - Fatih Kahraman** - Güllü Uysal***
}

\begin{abstract}
The aim of this study is to determine the main qualities of the coursebooks to be used in distance education by examining whether the New Istanbul Turkish for International Students is suitable in distance education. The present study also sheds light on the use of textbooks at the level of institutions and teachers who have started distance education following the pandemic, and it highlights textbook authors' efforts who are trying to develop convenient materials for distance education. The New Istanbul Turkish for International Students is designed for five language levels: A1, A2, B1, B2 and C1. The suitability of these books in distance education was made by document analysis method, which is one of qualitative research techniques used in this regard. The data were analyzed according to the following basic criteria: a. Whether the books have technological capabilities to facilitate their use in distance education, $b$. Whether the books are formally suitable for distance education, c. Whether the books are contextually suitable for distance education. As a result of the research, the teaching set is viewed as a Personalized Enriched Interactive book, and by using this teaching set, teachers can personalize the book by making additions to the book according to the readiness of the students in the class. Also, the learning units in the book are enriched with the support of video and audio files where the student can evaluate their own learning performance through the answer keys provided in the book. We noticed that student-teacher interaction is possible through the z-book feature and at the beginning of each unit; there is a section that includes learning objectives along with the theme and grammatical structures. The book also contains enough visual elements such as pictures, figures, graphics, symbols, and tables. This fact renders a suitable design of the book for the target audience. In addition,
\end{abstract}

\footnotetext{
* Doç. Dr., İstanbul Üniversitesi-Cerrahpaşa, Hasan Ali Yücel Eğitim Fakültesi, Türkçe ve Sosyal Bilimler Eğitimi Bölümü

Assoc. Prof. Dr., Istanbul University-Cerrahpasa, Hasan Ali Yücel Faculty of Education, Department of Turkish and Social Sciences Education 
contextual features such as the existence of instructions explaining the activities that students will do in the books, the presence of exercises to reinforce the given subject, the evaluation questions to control the extent to which the gains have been achieved which allows students to achieve learning agency.

StructuredAbstract: Introduction and purpose of the study: Distance language teaching is learning of a foreign language carried out without a physical presence in the school and without any time limitation when applicable. In this context, reaching the goals of distance language teaching depends on many factor that range from the readiness of the student to the presentation of the course to the planning of the instructional activities to the technological capabilities. Course materials are also one of the most important elements that ensure the success of distance language teaching. The aim of this study is to determine the main qualities of the textbooks to be used in distance education by examining whether the New Istanbul Turkish for International Students is suitable for use in distance education. This study is especially important in determining the features of textbooks to be used in distance education, especially for institutions and teachers who have started distance education due to the pandemic, and for textbook authors who are trying to develop suitable materials for distance education.

\section{Conceptual Framework}

With the communicative transformation that started in the 1970s, interaction and communication have become the center of language teaching. This transformation has also led to the focus on the inadequacy of traditional teaching methods in developing the four basic language skills in language teaching. In the mid1990s, the use of computer-based digital tools has become more common in distance language teaching. By this way, the tools used in language teaching in terms of interaction and communication have diversified and these tools have brought significant advantages to the teaching-learning process (Stickler, Hampel and Emke, 2020:133).

Since language teaching is a field that needs technological infrastructure, technological changes and developments are closely related to language teaching and the number of studies in this field is increasing rapidly. In addition to the concept of computer-assisted language learning, the concept of "mobile supported language learning has also entered the literature. Moreover, it is suggested that both concepts became obsolete. According to these views, computer-assisted language learning is limited to computers and it focuses conscious learning. Mobile assisted language learningcovers mobile electronic devices such as mobile phones, smartphones, palmtop computers, and tablets, laptops (Jarvis and Krashen, 2014: 5).

\section{Methods}

In this study, document analysis, one of the qualitative research techniques, was used and the New Istanbul Turkish for International Students published by the "KültürSanatBasımevi”" in 2020 was analyzed in the context of its suitability for use in distance education.

\section{Findings and Discussion}

New Istanbul Turkish for International Students is a Personalized Enriched Interactive set. Teachers using this teaching set can contribute to the book according to the readiness of students in their class, and thus, the teacher can personalize the book according to the situation of the students in the class. The units in the book are enriched with the support of video and audio files, and with the answer key presented in the book, the student can evaluate her/his own learning performance. Thanks to z-book feature of this set, international students can have the opportunity to learn Turkish from their own countries interactively just like in the classroom environment.

New Istanbul Turkish for International Students offers students the opportunity to learn the correct answer while working on their own, see other alternative answers about the question, and access to listening and video records through QR codes in every environment. In this way, it offers an opportunity for an interactive learning. The use of QR codes for listening and visual activities enables students to continue their learning activities in any environment, and does not limit students to only computer environments.

The books have a smart book feature that provides ease of use in individual studies and online lessons. Quick transition between pages can be made with the interface that can be projected on the screen, thanks to its basic features such as zooming the page, drawing on the page, drawing shapes, deleting, and adding text. This makes it easy for teachers to teach in the classroom as if they were teaching using the 
blackboard. In addition, users of the book can instantly access the changes and updates made by the book authors in the content of the books.

When the books were analyzed in terms of their formal features, we saw that each book consists of six units and at the beginning; there is a table of contents that explains the topics to be focused on in these units in addition to the activities to be solved in the expected language skills. Units, on the other hand, consist of three sections that contain six subject areas. The name and number of each section is given in the upper right corner of the pages. Moreover, on the first page of each unit, there are targets of that unit.

New Istanbul Turkish for International Students provides the opportunity to control to what extent the gains have been achieved with "What Have We Learned?" which is located at the end of each unit. Thanks to its feature of being an interactive book, it is possible to reach the versatile content through the activities on the book and the activities in the web-based application that can be accessed by reading the QR code. In addition the sections such as video assisted "Watch-Learn", "Daily Expressions" that covers the most encountered ones in daily life related to the topics in the unit, "Take Yourself", by which the student is able to record a video and upload it to the application, "You Have a Microphone" in order to improve the speaking skills, "One Step Beyond" in the interest of reinforcing the topic given in the unit and "What Have We Learned" activities for general assessment that enable the student to make a self-assessment are included. Students have the opportunity to carry out the activities without feeling the need of a teacher's assistance and figure out the right and the wrong by the access to the web-based application.

\section{Conclusions and Suggestions}

In language teaching, students need to interact with the teacher and other students, because the language skills may improve in this way. In distance education, when the lessons are held simultaneously, the student-teacher and the student-student interactions are feasible to some extent, however, this interaction is not possible in asynchronous lessons. For this reason, the materials to be used in distance language teaching should be prepared in accordance with the student's self-study and self-assessment.

Since the aim of language teaching is to let the students gain appropriate and effective communication skills, planning and studies should be carried out to develop communicative competence along with language skills, addressing the language in both its structural and functional dimensions. Accordingly, it can be said that the New Istanbul Turkish for International Students contributes to the improvement of the communicative competence of students in distance language teaching through the activities and interactive applications in all skills.

Keywords: Teaching Turkish as a foreign language, distance language education, textbooks, New Istanbul Turkish Teaching Book for International Students.

Öz: $\mathrm{Bu}$ araştırmanın amacı, uzaktan dil öğretiminde kullanılacak ders kitaplarının temel nitelikleri doğrultusunda Yeni İstanbul Uluslararası Öğrenciler İçin Türkçe Öğretim Setinin uzaktan öğretimde kullanıma uygun olup olmadığını belirlemektir. Bu çalışma özellikle salgın nedeniyle zorunlu olarak uzaktan dil öğretimine başlayan kurumlar ve öğretmenler ile uzaktan öğretime uygun materyal geliştirme çabasında olan ders kitabı yazarları için, uzaktan eğitimde kullanılacak ders kitaplarının taşıması gereken özellikleri belirlemesi noktasında önem taşımaktadır. A1, A2, B1, B2 ve C1 olmak üzere beş dil seviyesi için tasarlanmış olan Yeni İstanbul Uluslararası Öğrenciler İçin Türkçe Öğretim Seti'nin uzaktan öğretimde kullanıma uygunluk bakımından değerlendirildiği bu çalışmada, nitel araştırma tekniklerinden doküman analizi kullanılmıştır. Verilerin çözümlenmesinde şu temel ölçütler göz önünde bulundurulmuştur: a. Kitapların uzaktan öğretimde kullanımını kolaylaştıracak teknolojik olanaklara sahip olup olmadığı, b. Kitapların uzaktan öğretim için biçimsel açıdan uygun olup olmadığı, c. Kitapların uzaktan öğretim için içeriksel açıdan uygun olup olmadığı. Araştırma sonucunda incelenen öğretim setinin kişiselleştirilmiş zenginleştirilmiş etkileşimli bir kitap olduğu, bu öğretim setini kullanan öğretmenlerin sınıfındaki öğrencilerin hazırbulunuşluk durumuna gore kitaba eklemeler yaparak kitabı kişiselleştirebildiği, kitaptaki öğrenme ünitelerinin video ve ses dosyaları desteğiyle zenginleştirildiği, kitapta sunulan cevap anahtarı sayesinde öğrencinin kendi öğrenme durumunu değerlendirebildiği, kitabın z-kitap özelliği sayesinde öğrenci-öğretmen etkileşiminin mümkün olabildiği görülmüştür. Kitaplarda her unite başında dersin hedeflerinin, o ünitedeki temanın ve dil bilgisi yapılarının belirtildiği bir bölüm olduğu, kitaplardaki resim, şekil, grafik, sembol ve tablolar gibi görsel unsurların yeterli ölçüde kullanıldığı, kitapların tasarımının hitap 
ettiği kitleye uygun olduğu saptanmıştır. Ayrıca kitaplarda öğrencilerin yapacakları etkinlikleri açıklayan yönergelerin olması, verilen konunun pekiştirilmesini sağlayacak alıştırmaların bulunması, kazanımların ne ölçüde gerçekleştiğini control amaçlı değerlendirme sorularının olması gibi içeriksel özellikler, öğrencilerin kendi kendilerine çalışmalarına olanak tanıyacak niteliktedir.

AnahtarKelimeler: Yabancı dil olarak Türkçe öğretimi, uzaktan öğretim, uzaktan dil öğretimi, ders kitapları, Yeni İstanbul Uluslararası Öğrenciler İçin Türkçe Öğretim Seti.

\section{Giriş}

Uzaktan öğretim, öğrencinin okul ortamında bulunmadan ve herhangi bir zaman kısıtlamasına bağlı kalmadan öğrenme faaliyetlerini sürdürdüğü bir eğitim sistemidir. Uzaktan öğretimde öğrenme etkinliklerinin grçekleşmesi için zaman ve mekân kısıtlaması bulunmaması, öğretmenlere ve öğrencilere için esneklik tanımaktadır. Aynu anda çok sayıda öğrenciye ulaş1labilmeye olanak sağlayan uzaktan eğitim, örgün öğretime katılamayan öğrenciler için firsat eşitliği yaratmaktadır.

Uzaktan öğretim, eğitimin veriliş biçimine, kullanılan araçlara, öğrenme ortamına göre araştırmacılar tarafından farklı şekillerde tanımlanmıştır. Moore ve Kearsley’e (2012: 2) göre uzaktan eğitim, öğretmen ve öğrencinin farklı yerlerde olduğu ve özel bir kurum tarafindan planlı bir şekilde tasarlanan öğrenme ve öğretme sürecidir. Uzaktan eğitim, öğrencilerin ve öğretmenlerin fizikî olarak aynı ortamda bulunmadığı (Adıyaman, 2002; Al ve Madran, 2004; Keegan, 1980; Moore ve Kearsley, 2012), öğrencinin bağımsız olduğu, böylece öğretmen ve öğrencinin zorunlu iş yükünden kurtulduğu esnek bir öğretim sistemidir (Wedemeyer, 1981). Elektronik olan ya da olmayan sistemler aracılığıyla özel iletişim yöntemleriyle gerçekleştirilerek zaman ve mekân sınırlarını ortadan kaldıran birçok öğrenme faaliyetini kullanıcılara sunan planlı, tasarlanmış, kapsamlı bir öğrenme modelidir (Altıparmak Vd., 2011: 320). Uzaktan eğitim, düşük maliyetle nitelikli bir eğitim gerçekleştirilmesini amaçlayan, farklı sebeplerle eğitim ortamından uzak kalan bireylere firsat eşitliği sunan, teknolojik araçlarla geniş kitlelere erişebilen eğitim biçimidir (Elitaş, 2017).

Yukarıdaki tanımlar ve bu alanda yapılan çalışmalar (Altıparmak Vd., 2011; Elitaş, 2017; İşman, 2008; Kaya, 2002; Keegan, 1980; Kırık, 2014; Özaraslan, 2008; Taylor 2011; Wang ve Sun, 2001) incelendiğinde, uzaktan eğitimin temel özellikleri şu şekilde sıralanabilir:

- Öğrenme etkinliklerinin gerçekleşmesi için zaman ve mekân kısıtlaması yoktur.

- Bir kurum tarafindan planlı bir şekilde tasarlandığı için, öğrenci başarılı olduğu takdirde diploma, sertifika alabilme şansına sahiptir.

- Aynı anda çok sayıda öğrenciye ulaşılabildiği için düşük maliyetlidir.

- Çeşitli nedenlerle örgün öğretime katılamayan bireylere firsat eşitliği sunar.

- Örgün öğretime göre daha geniş kitlelere ulaşma imkânı vardır.

- Çeşitli teknolojik araçlarla öğrenci - öğretmen arasında etkileşime olanak sağlar.

- Psikolojik faktörler devrede olmadığı için öğrenci, kendini öğretmen baskısı altında hissetmeden özgür iradesi ile öğrenme faaliyetini gerçekleştirmektedir.

- Uzaktan eğitim hem eşzamanlı (senkron) hem de eşzamansız (asenkron) bir şekilde gerçekleştirilebilmektedir.

- Teknolojik olanaklar sayesinde öğrenciye hızlı geribildirim verilebilmektedir.

Uzaktan eğitimin tarihi, günümüzden yaklaşık üç yüz yıl önceye dayanmaktadır. 1728'de Boston Gazetesi'nde mektupla steneogrofi derslerinin verileceğine, 1833'te bir İsveç gazetesinde 
mektupla yazılı anlatım dersi verileceğine ilişkin ilan bulunmaktadır. Bilinen ilk uzaktan eğitim uygulaması İngiltere'de, Isaac Pitman tarafından 1840'ta başlatılmıştır. Isaac Pitman, öğrencilerine mektupla steneogrofi eğitimi vermiş, İncil'in bazı bölümlerini steno ile yazmayı öğretmiştir. Bu uzaktan eğitim uygulamasının sonunda öğrencilere sınav uygulanmış ve öğrenci başarıları notla değerlendirilmiştir. 1856 yılında uzaktan öğretim daha sistemli hâle getirilmiş; Charles Toussaint ve GustavLangenscheid Almanya'da uzaktan eğitim uygulayan bir dil okulu kurmuşlardır. 1874'te Amerika Birleşik Devletleri'nde Illinois Wesleyan Üniversitesi hem lisans hem de lisansüstü düzeyde uzaktan öğretim yoluyla eğitim veren programlar açmıştır. 1883'te yine Amerika Birleşik Devletleri'nde (New York Ihaca) Mektupla Eğitim Üniversitesi kurulmuştur. 1884'te Almanya'da öğrencileri üniversite sınavına hazırlamak amacıyla Rustinches Uzaktan Öğretim Okulu açılmıştır. 1890'da Avustralya Queensland Üniversitesi açık öğretim programı yürütmeye başlamıştır. 1892'de Amerika Birleşik Devletleri'nde Chicaco Üniversitesi'nde uzaktan eğitim bölümü açılmıştır. 1894 yılında, İngiltere'de dışarıdan öğretmenlik sertifikası almaya hazırlanan öğrencilerin kendi aralarında yazı ile bilgi alışverişinde bulunmalarını sağlayan bir sistem oluşturulmuştur. 1898 'de İsveç'te, HansHermod tarafindan uzaktan eğitim veren bir lise açılmıştır. 1900'lü yıllarda ise dünyada mektupla öğretimin yanında, radyo ve TV programlarıyla, bu yüzyılın son çeyreğinden itibaren de bilgisayar ve internet teknolojileriyle uzaktan öğretim faaliyetleri yürütülmeye başlamıştır. Özellikle Avrupa'da ve Amerika Birleşik Devletleri'nde pek çok üniversitede açık öğretim ve uzaktan eğitim programları açılmıştır (Arar, 1999; Arslan, 2011; İşman, 2008; Kaya, 2002; Kırık, 2014; Lease ve Brown, 2009; Verduin ve Clark, 1994).

Türkiye'de uzaktan eğitim konusu 1927-1960 arasında çeşitli defalar gündeme gelmiş, mektupla okuma yazma öğretimi yoluyla okuryazarlığın yaygınlaştırılması planlanmış ancak bu düşünceler hayata geçirilememiştir. Ülkemizde ilk uzaktan eğitim uygulaması, 1956'da Ankara Üniversitesi Hukuk Fakültesi Banka ve Ticaret Hukuku Araştırma Enstitüsü tarafından banka çalışanlarına mektupla eğitim vermek suretiyle gerçekleştirilmiştir. MEB tarafından verilen ilk uzaktan eğitim uygulaması ise 7.11.1960 tarihinde "Mektupla Öğretim" adıyla başlamıştır. 26.2.1966 tarihinde Mektupla Öğretim ve Teknik Yayınlar Genel Müdürlüğü, 5.6.1974 tarihinde ise Mektupla Öğretim Merkezi kurulmuştur. Mektupla Öğretim Merkezi, 26.9.1975 tarihli Bakanlık onayı ile kurulan Yaygın Yükseköğretim Kurumuna (YAYKUR) bağlanmıştır. 1982 y1lında Anadolu Üniversitesi bünyesinde öğretim, araştırma ve yayın hizmetleri veren Açık Öğretim Fakültesi açılmıştır. İlk yıl İktisat ve İş İdaresi lisans programlarına 29.500 öğrencinin kaydolması, yükseköğrenim ihtiyacının ve talebinin boyutlarını açıç̧a ortaya koymuştur. 19821993 yılları arasında Türkiye'de, Anadolu Üniversitesi'nin sunduğu açık öğretime olan talep hızla artmıştır. MEB ile imzalanan protokol gereğince yaklaşık 200.000 öğretmene önlisans ve lisans tamamlama olanağı sunulmuştur. Anadolu Üniversitesi’nin ardından, ODTÜ, İTÜ, Firat, Sakarya ve İstanbul Üniversitesi başta olmak üzere pek çok üniversite uzaktan eğitim hizmeti sunmaya başlamıştır (Arslan, 2011; Bozkurt, 2017; Kaya, 2002).

Ülkemizde sadece yükseköğretim düzeyinde değil; ilköğretim ve ortaöğretim düzeyinde de uzaktan eğitim faaliyetleri yürütülmektedir. Bunun ilk örneği, Milli Eğitim Bakanlığı'nın 2.6.1992 tarihli yazısı ile kurulan Açıköğretim Lisesi'dir. Dersler için TRT'de televizyon programları yayınlanan bu liseye, ilk yıl yaklaşık 45.000 öğrencinin kayıt yaptırması, Türkiye'de açık liseye duyulan ihtiyacı göstermesi bakımından önemlidir. Açıköğretim Lisesinin ardından, 1997'de Açık İlköğretim Okulu kurulmuştur ve bu okula kurulduğu ilk y1l 70.000 civarında öğrenci kaydolmuştur (http://aol.meb.gov.tr).

Mart 2020'den itibaren tüm dünyada olduğu gibi ülkemizde de etkisini gösteren Kovid-19 salgını sonrasında, virüsün yayılma hızını azaltmak için alınan önlemler gereği uzaktan eğitim bir alternatif olmaktan çıkıp bir zorunluluk hâline gelmiştir. Bu süreçte üniversiteler kendi uzaktan eğitim sistemlerinin yanında, Zoom, Google Meet, Google Classroom, Canvas, Microsoft Teams, Adobe Connect gibi platformlarda canlı ya da asenkron derslerle eğitim faaliyetlerini yürütmektedir. İlk ve orta dereceli okullarda ise bu sayllan platformlarda ve EBA'da yürütülen 
canlı derslerin yanında, EBA TV üzerinden de ders yayınları yapılmaktadır. Uzaktan eğitimin başladığı 23 Mart 2020'den 27 Kasım 2020'ye kadar EBA TV üzerinden okul öncesi, ilkokul, ortaokul ve lise öğrencileri için 8914 saat yayın yapılmıştır (http://yegitek.meb.gov.tr/).

Uzaktan eğitimin gerek dünyadaki gerekse ülkemizdeki seyri incelendiğinde, uygulamaların mektupla başlayıp zamanla bilgisayar ve internet destekli çalışmalara doğru ilerlediği görülmektedir. Taylor (2001: 3), uzaktan eğitimdeki uygulama aşamalarını ve bu aşamaların sağladığı olanakları şu şekilde tablolaştırmıştır:

Tablo 1: Uzaktan Eğitim Uygulama Modelleri İçin Kavramsal Çerçeve (Taylor, 2001:3)

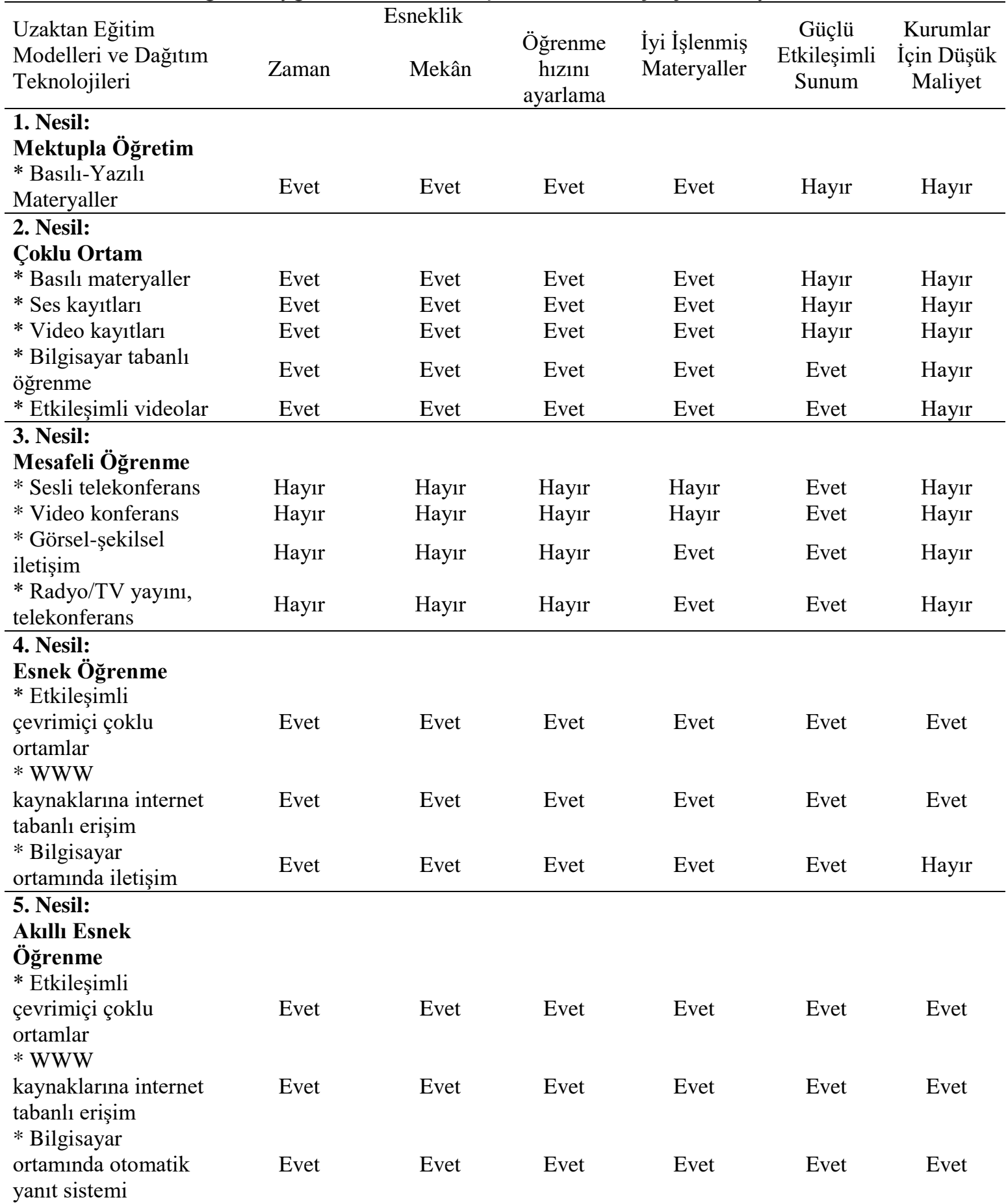


kullanarak iletişim

* Kampüslerin

kurumsal çalışmalarını ve kaynaklarını web portalları üzerinden erişime açması

Tablo 1 incelediğinde, ilk nesil uzaktan eğitim modelinin mektupla gerçekleştiği, yazılı ve basılı materyallere dayandığı görülmektedir. Yeni bir konuyu öğrenmek için uzun bekleme süresi gerektiren bu model, radyo ve televizyonun icadıyla yeni paylaşım ortamının bulunduğu 20. yüzyılın ilk yarısına kadar sürmüştür. Mektupla ve basılı materyallerle uzaktan eğitimin gerçekleştirildiği bu model, öğrenciye zaman kullanımı, her hangi bir mekâna bağlı olmama ve öğrenme hızını ayarlama konusunda esneklik sağlamaktadır. Bununla beraber bu modelin öğrenciöğretmen etkileşimini sağlamaması ve uzaktan öğretimi düzenleyen kurumlar açısından yüksek maliyetli olması gibi olumsuzlukları bulunmaktadır.

İkinci nesil uzaktan eğitim, basılı materyaller, ses ve video bileşenlerini içermektedir. Bu modelde eğitim malzemesi olarak basılı materyaller, ses ve videokasetleri ile etkileşimli videolar kullanılmaktadır. İkinci nesil uygulamalar, ses ve görüntü ögeleri de barındırdığından, özellikle yabancı dil öğretiminde dört temel dil becerisinin geliştirilmesi için daha fazla olanak sunmaktadır. Çoklu ortam modeli olarak adlandırılan bu model, öğrenciye zaman kullanımı, her hangi bir mekâna bağlı olmama ve öğrenme hızını ayarlama konusunda esneklik sağlamakta, iyi yapılandırılmış ders materyallerine ulaşma ve sınırlı da olsa öğretmen-öğrenci etkileşimi konusunda avantajlar sunmaktadır.

Uzaktan eğitimde üçüncü nesil, sesli telekonferans, video konferans, e-posta yoluyla görsel-yazılı iletişim, radyo/TV yayını gibi olanakların bulunduğu bir dönemdir. Bu modelde her ne kadar bilgisayar kullanılsa da bilgisayar birincil bir öğrenme ortamı değil, bir yardımcı gereç niteliğindedir. Ses ve görüntü teknolojilerinin uzaktan eğitim ortamında kullanımının yaygınlaşması, özellikle yabancı dil öğretimi alanında çığır açmış, bu dönemde uzaktan dil okullarının sayısı artmıştır. Üçüncü nesil uzaktan öğretimde telekonferans, video konferans gibi araçların kullanımı, öğrenci - öğretmen etkileşimini arttırmakla birlikte, öğrenciye öğrenme zamanını, mekânını ve öğrenme hızını ayarlama konusunda bir takım kısıtlamalar da getirmiştir.

Esnek öğrenme modeli olarak da adlandırılan dördüncü nesil, internet ve bilgisayar olanakları ile dikkati çekmektedir. Bu olanaklar sayesinde senkronize iletişimin sağlanması, özellikle dil öğretimi açısından çok önemlidir çünkü yabancı dil öğrenenler, o dili ana dili olarak konuşanlar ile etkileşime geçebilmektedirler. İnternet üzerinden telefon görüşmesi, video konferans, sanal topluluklar ve gerçek zamanlı teknolojileri kullanan sanal sınıflar, dördüncü nesil uzaktan öğretimin sunduğu yeniliklerdir (Wang ve Sun, 2001). Dördüncü nesil uzaktan öğretimde senkronize iletişimi sağlayan internet ve bilgisayar olanaklarının kullanımı, hem öğrenciye zaman, mekân ve öğrenme hızını ayarlama konusunda esneklik sağlamakta hem de öğretmen-öğrenci etkileşimine ve öğrenme materyallerine ulaşmaya olanak tanıdığı için etkili bir öğrenme ortamı oluşturmaktadır.

Uzaktan öğretimde beşinci nesil, akıllı-esnek öğrenme modeli olarak adlandırılmaktadır. Akıllı-esnek öğrenme modeli, internet tabanlı sunum bağlamında otomatik yanıt sistemleri ile akı1lı nesne veri tabanlarının kullanımını birleştirerek, öğrencilere neredeyse sıfıra yakın maliyetle kişiselleştirilmiş bir öğrenme ortamı sağlamaktadır (Taylor, 2011: 12). Ayrıca kampüslerin kurumsal çalışmalarını ve kaynaklarını web portalları üzerinden erişime açması, sadece uzaktan eğitim öğrencileri için değil, örgün eğitim öğrencileri için de bilgiye ulaşmayı kolaylaştıran önemli bir yeniliktir. 


\section{Uzaktan Dil Öğretimi}

Teknolojik gelişmelerin bir sonucu olarak ülkeler arası iletişimin artmasıyla yabancı dil öğrenimine olan ihtiyaç da artmıştır. Günümüz dil bilimi anlayışına göre, dil öğretimi bir gramer öğretiminden ziyade bir dil becerisi kazandırma süreci olarak kabul edilmektedir. Günümüzde dil çalışmaları ve öğretimi ses bilimi, biçim bilgisi, söz dizimi, sözcük bilimi, anlam bilimi ve lehçe bilimi gibi başlıklar altında yürütülmektedir. Bu açıdan bakıldığında yabancı dil öğretiminde teknolojinin hizmete sunduğu araç ve uygulamaların yardımıyla gelişmiş öğrenme ortamlarının oluşturulması ve bu imkânlardan beceri alanlarına göre uygun olanlarının etkili ve verimli bir șekilde kullanılması gerekmektedir. Aksi takdirde böylesine kapsamlı bir dil öğretim sürecinin başarıya ulaşması ya mümkün olmayacaktır ya da uzun zaman alacaktır. Nitekim dijital öğrenme kavramı hem Millî Eğitim Bakanlığının hazırlamış olduğu programlarda (MEB, 2019) hem de Avrupa Dilleri Ortak Başvuru Metninde (Council of Europe, 2018) yer almaktadır.

1970'li yıllarda başlayan iletişimsel dönüşüm ile birlikte etkileşim ve iletişim, dil öğretiminin merkezi hâline gelmiştir. Bu dönüşüm aynı zamanda geleneksel öğretim metotların dil öğretiminde dört temel dil becerisinin geliştirilmesi konusunda ne ölçüde yetersiz kaldığı üzerine de odaklanılmasına yol açmıştır. 1990'lı yılların ortalarına gelindiğinde bilgisayar tabanlı dijital araçların kullanılmaya başlanması, uzaktan dil öğretimini daha yaygın hâle getirmiştir. Bu sayede dil ögrretiminde etkileşim ve iletişim açısından kullanılan araçlar çeşitlenmiş ve bu araçlar öğretmeöğrenme sürecine önemli kolaylıklar getirmiştir (Stickler, Hampel ve Emke, 2020: 133). Basıl1 materyallerin kullanımı ile başlayan uzaktan yabancı dil öğretiminde, gelişen teknolojiye bağlı olarak; disketler, video-kasetler, CDROM'lar, radyo, televizyon, bilgisayar, internet ortamı, mobil teknolojiler ve son olarak da sanal dünyadaki uygulamalar yer almaya başlamıştır (Pilanc1, 2015: 256).

Diğer taraftan, dil öğretiminin teknolojik alt yapıya ihtiyaç duyan bir alan olması nedeniyle yaşanan teknolojik değişim ve gelişmeler, dil öğretimini yakından ilgilendirmekte ve bu alanda çalışmalar hızla devam etmektedir. Bu bağlamda, son dönemde "bilgisayar destekli dil öğrenimi" (computer-assistedlanguagelearning-CALL) kavramının yanında "mobil destekli dil öğrenimi" (mobile-assistedlanguagelearning-MALL) kavramı da alanyazına girmiştir. Bilgisayar destekli dil öğrenme, bilgisayarla sınırlıdır ve bilinçli öğrenmeyi ifade etmektedir. Mobil destekli dil öğrenme; cep telefonları, akıllı telefonlar, avuç içi bilgisayarlar, tabletler, diz üstü bilgisayarlar gibi taşınabilir elektronik araçları kapsamaktadır (Jarvis ve Krashen, 2014: 5).

Özellikle dil öğrenenlerin uzaktan eğitim gibi değişik ihtiyaçlarına cevap vermeyi hedefleyen bilgisayar yazılımlarının ve uygulamalarının kullanılması, geleneksel öğretim yöntemlerinde kabul görmüş etkinliklerden farklı uygulama örnekleri ortaya çıkarmakta ve artık öğrenme süreçlerinin kalitesini büyük ölçüde bu paradigmalar belirlemektedir (Özperçin vd., 2015: 138). Dil öğretimi açısından çok zengin olan bilgisayar programlarına ek olarak, yazım denetimi, çevrimiçi sözlük ve çevrimiçi çeviri programı gibi yaygın kullanılan bilgisayar araçları da öğrencilere, hedef dili kendi kendilerine analiz edebilecekleri olanaklar sağlamaktadır. Böylece, bilgisayar programları, internet ve çevrimiçi kaynaklar sayesinde, öğrenciler aktif olarak öğrenme sürecinin merkezinde konumlanabilmektedir.

Etkili bir öğrenme yolu olan çevrim içi öğretimin tek faydası, dil alanında çalışanlara yeni bir ortam sunmak değil; aynı zamanda onlara öğrenci merkezli bir öğretimin başka nasıl gerçekleştirilebileceğine dair yeni pencereler açmaktır. Zor olmasına karşın, ikinci veya yabancı dil eğitimi alanında uygun teknolojileri ve stratejileri öğrenme sürecine aktararak geleneksel dil öğretim yöntemlerinin eksikliklerinin giderilmesi gerekmektedir. Çünkü dil öğreticileri ve öğrenicileri giderek artan düzeyde internet tabanlı uygulamalara, programlara ve materyallere ihtiyaç duymaktadır. Bu ihtiyacın muhtemel sebebi bu tür ders araçlarının esnek, ilgi çekici ve eğlenceli olmasıdır (Jabeen ve Thomas, 2015). 
Günümüzde çevrimiçi dil öğretimi açısından hâlihazırda birçok uygulama mevcuttur. Gerek dünyada gerekse ülkemizde çeşitli üniversiteler yabancı dil öğretimi alanında yeni uygulama modelleri geliştirmektedir. Örneğin Yale Üniversitesinin Dil Öğretim Merkezi çevrimiçi dil öğretim araçlarını, ses kaydı ve düzenleme, fotoğraf düzenleme, multimedya projeleri, işbirlikçi çalışma ve yazma, sunum, video konferans, sözlük ve kelime öğrenimi, video yapımı ve düzenlemesi ile website ve portfolyo hazırlanması şeklinde kategorize etmiştir (https://cls.yale.edu/faculty/resources/online-teaching-tools-and-resources). Anadolu Üniversitesi Uzaktan Türkçe Öğretim Programında ise öğrencilere; ders çalışma, video, kitap, çalışma kitabı, ödevler, eşzamanlı danışmanlık hizmetleri, ayrı zamanlı danışmanlık hizmetleri, deneme sınavı, sözlü sınav, yazılı sınav olmak üzere on bir ayrı öğrenme ortamı sunulmuştur (Pilanc1, vd, 2015: 1283). Ankara Üniversitesinin Uzaktan Türkçe Öğrenme Portalında ise okuma, dinleme, yazma ve konuşma becerilerini geliştirmeye yönelik çeşitli öğretim etkinlikleri bulunmaktadır (https://ankuzef.ankara.edu.tr).

İnternet tabanlı uzaktan dil öğretim programları öğrencinin kendi kendine çalışmasına olanak sağlayan, öğrenci merkezli materyalleri içerir. Bilgisayarlarda eşzamanlı ya da eşzamanlı olmayan teknolojilerle kullanılabilen bu materyaller, etkileşimli öğrenme ve bireysel öğrenme olmak üzere iki önemli özellik taşımaktadır. Aynı program üzerinde eşzamanlı ve eşzamanlı olmayan teknolojileri birlikte kullanmak da mümkündür. Eşzamanlı olmayan öğretim yönteminde öğrenciye bir anlamda paketlenmiş bir ürün takdim edilir. Öğrencinin bunu alıp tüketmesi ve sonrasında öğrenimin gerçekleşmesi hedeflenir ancak etkileşim imkânı olmadığı için bu yöntemde başarı olanağı düşüktür. Çünkü burada yetersiz etkileşim, anında geri bildirimin yapılamıyor olması, öğrenmenin gerçekleşmesi bakımından yeterli uygulama olanaklarının bulunmaması ve eğitimde teknoloji kullanımına dair bilgi eksikliği, senkronize olmayan öğretimin beklenen düzeyde verimli olmamasının en temel sebepleri arasında düşünülebilir. Ayrıca konuşma becerisinin geliştirilmesinde etkileşimli bir ortamın bulunmaması da eş zamanlı olmayan öğretimin dezavantajlarından biridir.

Öğretmen gözetiminde ve rehberliğinde yapılan bir öğretimin verimi önemli derecede artırdığı bilinmektedir (Fidan, 2012; Kaya, 2002; Küçükahmet, 2004; Senemoğlu, 2018). Bu sebeple daha esnek, ulaşılabilir, ucuz, verimli ve birçok gelişmiş teknolojik uygulama ve programa sahip eş zamanlı çevrim içi öğretim ile konuşma becerisi başta olmak üzere tüm dilsel becerilerin istenen düzeyde geliştirilmesi sağlanabilir. Belirtilen bu hedeflere ulaşmak için, öğretim sürecinin tarafları olan öğrenci ve öğretmenlerin çevrimiçi öğretim ile bu öğretimin gerçekleşmesi aşamasında gerekli teknik bilgi açısından desteklenmesi, bu sayede de başarının artması sağlanmalıdır. Çevrimiçi dil öğretimi sırasında konuların bir bağlam içinde sunulmasına, yeni gelişmeleri takip ederek uygulamaların çeşitlendirilmesine, bilginin işbirliği ile inşasına ve

öğrencilerin öğrendikleri yeni bilgileri kullanabilecekleri ortamın oluşturulmasına dikkat edilmelidir.

Çeşitli platformla üzerinden gerçekleştirilen canlı dersler, bloglar, video paylaşım siteleri, sosyal medya uygulamaları gibi eşzamanlı ya da eş zamanlı olmayan yollarla gerçekleştirilen uzaktan dil öğretiminin öğrenciler ve öğretmenler açısından çeşitli avantajları ve dezavantajları bulunmaktadır. Uzaktan dil öğretiminin avantajlarını ve dezavantajlarını alan yazından (Adıyaman, 2002; Birinci, 2020; Göker, 2019; Husmann ve Miller, 2001; Kadızade, 2015; Karasu ve Sar1, 2019; Mutlu ve Tuga, 2013; Özgöl, Sarıkaya ve Öztürk, 2017; Pilanc1, 2009; Pilanc1, Saltık ve Zenci, 2020; Şen, 2016; Yaman, 2015) elde ettiğimiz bilgiler ve kendi deneyimlerimiz ışığında şu şekilde sıralayabiliriz.

Avantajlar1:

- Kaynak ya da öğretmen eksiğinde dil öğrenenlere firsat eşitliği sağlar. 

destekler.

• Öğrencileri zaman, mekân ve eğitim şartları açısından özgürleştirerek öğrenen özerkliğini

- Sürekli eğitim olanağı sağladığı için öğrenciler tarafından ilgi çekicidir.

- Geniş kitlelere ulaşmayı kolaylaştırır.

- Dil öğrenme maliyetini düşürür.

- Görsel ve işitsel materyallerin daha sık kullanılmasına olanak sağlar.

- Öğrencilere kendi kendilerine dil öğrenme imkânı sunar.

- Öğrenci merkezli dil öğretiminin gerçekleşmesine olanak sunduğu için öğrencilerin güdülenmelerini arttırır.

Dezavantajları:

- Öğrenciler ile öğretmenlerin doğrudan etkileşim içinde olmamaları, öğretmenlerin ve öğrencilerin motivasyonunu düşürebilir.

- Öğrencilerin bireysel farklılıklarının belirlenmesi zor olabilir.

- Öğretim sürecinde ortaya çıkan problemlere anında müdahale edilemeyebilir.

- Üretici dil becerileri olan konuşma ve yazma becerisinin gelişimini olumsuz etkileyebilir.

- Ölçme ve değerlendirme süreci tüm dil becerilerinde eşit gerçekleştirilemeyebilir.

- Ders materyali uzaktan eğitimin gereklerini karşılamada yetersiz kalabilir.

- Derse hazırlık sürecinde öğretmenin iş yükü artabilir.

Dil öğretiminde firsat eşitliğini sağlaması, eğitimin geniş kitlelere ulaştırılması ve kişinin kendi kendine dil öğrenmesine olanak tanıması bakımından, uzaktan dil öğretim teknolojilerinin yaygınlaşmasıyla yabancı dil öğrenenlerin sayısında artış olacağı öngörülmektedir. Yukarıda sıralanan maddeler incelendiğinde, uzaktan eğitimin sağladığı avantajların dezavantajlardan daha fazla olduğu, dezavantaj olarak görülen durumların da iyi planlanan eğitim ortamlarıyla ve iyi hazırlanmış ders materyalleriyle ortadan kaldırılabileceği görülmektedir.

\section{Uzaktan Dil Öğretiminde Kullanılan Materyaller}

Dil öğretiminde ders kitapları, gerek yüz yüze gerekse uzaktan eğitimde, hedef kazanımların gerçekleşmesinin en temel araçlarından biridir. Ders kitapları, öğretim programında belirtilen amaçlara ulaşılmasında, içeriğin aktarımında, öğretme sürecinin gerçekleşmesinde ve ölçme-değerlendirmenin yapılabilmesinde hem öğretmen hem de öğrenci için çok önemlidir (Kılıç ve Seven, 2002). Diğer bir deyişle, dersin öğretimi için uygulanan öğretim programiyla paralel bir şekilde ilerleyen ve belli bir kurum tarafından onaylanan temel kaynaklardır (Gülersoy, 2013).

Günümüzde gelişen teknoloji sayesinde kitap, video ve dinleme metinlerinin yanı sıra web siteleri, e-kitaplar, podcastler, vikiler, çevrim içi oyunlar, bloglar, anlık mesajlar, sosyal medya paylaşımları ve e-postalar dil öğretiminde kullanılabilmektedir. Uzaktan dil öğretiminin hedeflerinin gerçekleşmesi, öğrencinin hazır bulunuşluğundan dersin sunumuna, öğretim etkinliklerinin planlanmasından sahip olunan teknolojik imkânlara kadar pek çok unsura bağlıdır. Ders materyalleri de uzaktan dil öğretiminin başarıya ulaşmasını sağlayan en önemli unsurlardan biridir.

Dünyada olduğu gibi Türkiye'de de ders kitapları, dil öğretim sürecinin vazgeçilmez unsurlarından biridir. Uzaktan eğitim uygulamalarında ders kitaplarının rolü incelendiğinde ders kitaplarının temel öğrenme ortamı olma özelliğini açık bir şekilde görmek mümkündür. Avrupa'nın önde gelen açık üniversitelerine bakıldığında, İngiltere'de bulunan Açık Üniversite öğrencilerinin 
ders çalışma sürelerinin yüzde 75'ini; Almanya'da bulunan Açık Üniversite öğrencilerinin ise ders çalışma sürelerinin yüzde 80'ini ders kitapları ile geçirdikleri görülmüştür. Türkiye'de de durum farklı değildir. Anadolu Üniversitesi Açıköğretim Fakültesi öğrencileri ve Millî Eğitim Bakanlığının Açıköğretim Lisesi öğrencileri de ders çalışma zamanlarının önemli bir kısmını ders kitaplarından çalışarak geçirmektedirler. (Kaya, 2002: 92)

Günümüzde, öğretim teknolojilerinin ve yöntemlerinin gelişmesi ve çeşitlenmesiyle birlikte ders kitaplarının önemi bir kat daha artmış (Seguin, 1989); kitapların teknolojik gelişmelere uyum sağlaması gerekliliği ortaya çıkmıştır. Gelişen teknolojik alt yapının etkisiyle, farklı platformlarda gerçekleştirilebilen uzaktan dil öğretimine duyulan ilginin artmasıyla materyallerin uzaktan eğitime uygunluğu üzerine çalışmalar hız kazanmıştır. En temel öğretim araçlarından biri olarak kabul edilen ders kitapları bu çalışmaların merkezinde yer almıştır.

Öğretim materyallerinde bulunması gereken en önemli özellik, materyalin dersin amacına ulaşmasına hizmet etmesidir. Dil öğretiminde kullanılacak materyaller öğrencilerin, dört temel dil becerisi olan okuma, dinleme, konuşma ve yazma alanlarında yetkinliğe kavuşmasını amaçlamalıdır. Öğrencinin dilin kullanımına ilişkin zengin örneklerle karşılaşması bu amaca ulaşılmasına katkı sağlar. Bu nedenle dil öğretiminde kullanılan materyallerin görsel ve işitsel açıdan da zengin olması önemlidir.

Dil öğretiminde öğrencilerin öğretmenle ve birbirleriyle etkileşim içinde bulunması gerekmektedir çünkü dilin kullanımı bu yolla gelişmektedir. Uzaktan eğitimle yapılan derslerde, öğrenci-öğretmen ve öğrenci-öğrenci etkileşimleri derslerin eş zamanlı ilerlediği durumlarda sinırlı olarak mümkünken eş zamanlı olmayan derslerde bu etkileşim gerçekleşememektedir. Uzaktan yapılan derslerde öğrenciler, etkileşimde bulunma olanağına sınırlı seviyede sahip oldukları ya da hiç sahip olamadıkları için tasarlanan materyallerin pek çoğu öğrencinin kendi başına çalışabilmesine de uygun olarak hazırlanmalıdır. Yavuz, Hasançebi ve Kurşun (2020), e-kitapların öğretmenlerden ziyade öğrencilerin kullanımı amacıyla hazırlanma, özel bir kitle için tasarlanma, öğrencilerin bireysel değerlendirmelerine firsat verme ve esnek bir içerik sunma gibi özelliklere sahip olması gerektiğine değinir. Kaya (2002) ise uzaktan eğitim faaliyetleri için hazırlanan ders kitaplarının yazılı bir ders materyali olmanın yanında, bir ögretmenin görevlerini yerine getirecek şekilde tasarlanması gerektiğini ifade eder. Yüz yüze eğitim faaliyetlerinde kullanılan ders kitapları öğrencilerin bireysel öğrenmelerine odaklanmazken, uzaktan eğitim için hazırlanan ders kitapları öğrencilerin kendi başına öğrenmelerine ortam hazırladığı için öğrenme hızının ayarlanmasında da öğrenciye özgürlük sağlamalıdır. Kolay taşınması ve öğrenciyi belli bir zamana ya da mekâna mahkûm kılmaması gibi olumlu özelliklerinin yanında, uzaktan eğitim için hazırlanan ders kitapları, kolayca çoğaltılıp güncelleştirilebilme niteliğine de sahip olmalıdır.

Uzaktan eğitime özel olarak hazırlanan ders kitaplarının taşıması gereken temel özellikleri alanyazından derlediğimiz çalışmalardan (Başal, 2013; Bozkurt ve Bozkaya, 2015; Diaz, 2003; Kaya, 2002; Weimin ve Dhanarajan, 1999; Yalman ve Başaran, 2018) ve kendi öğretim deneyimlerimizden hareketle şu şekilde sıralayabiliriz:

* Ders kitabında bölüm numarasının ve adının yazıldığı bir kısım olmalıdır.

* Öğrencinin okuyacağı bölümün hangi öğrenme hedeflerine sahip olduğu maddeler halinde belirtilmelidir.

* Her bölümün ana ve alt başlıklarının gösterildiği içindekiler bölümü olmalıdır. Öğrencinin genel olarak neler ile karışılacağı bu bölümde belirtilmelidir.

* Öğrencilerin hangi etkinlikleri ne şekilde gerçekleştireceklerini açıklayan yönergeler net olarak sunulmalıdır. 
* Asıl metinde işlenen içeriğin, uygulama aşamasının gerçekleşmesi için alıştırmalar bölümü yer almalıdır. Bu bölümde dil bilgisi konusunun alıştırma örnekleri ve öğretilen dil bilgisi kuralının hangi bağlamlarda kullanıldığı kapsamlı bir şekilde sunulmalıdır.

* Bölüm başında yer alan kazanımların ünite sonunda ne ölçüde gerçekleştiğinin test edilmesini sağlayan bir bölüm yer almalıdır. Böylece öğrencinin kendi öğrenmesini kontrol etmesine olanak tanınmalıdır.

* Ders kitabındaki metinler öğrencilerin seviyesine uygun olmalı, öğrencilerin okuma ve kavrama düzeyleri göz önünde bulundurulmalı ve ön bilgileri dikkate alınmalıdır.

* Kitapların tasarımı ve kapsamı belirlenirken hitap edilecek kitlenin yaşı, dil yetenekleri, okuma biçimi ve alışkanlıkları göz önünde bulundurulmalıdır.

* Öğrencilere sunulacak bilgiler, belli bir düzene göre aktarılmalıdır. Her bir konu kendisinden sonrakine hizmet edecek şekilde planlanmalı ve dersin amaçlarına ulaşmayı destekler nitelikte olmalıdır.

* Öğrenciler uzaktan eğitim yoluyla hedef dilin konuşulduğu ülke dișında da dil öğrenebilirler, bu nedenle kitaplarda o dilin içinde geliştiği kültürün öğretimine de yer verilmelidir.

* Kitaptaki resimler, şekiller, grafikler, semboller, tablolar gibi görsel unsurlar, hem metnin bağlamına hem de öğrencilerin düzeyine uygun olmalıdır. Ders kitaplarında kullanılacak görseller, bilimsel bir yaklaşımla belirlenmelidir. Göstergebilimsel açıdan ele alınıp hem seviyeye uygunluğuna hem de içeriğe uygunluğuna dikkat edilmelidir. Buna ek olarak, renk tercihleri de çok önemlidir. Renklerin seçimine ve bu renklerin işlevsel bir şekilde kullanıma dikkat edilmelidir.

* Yazım kurallarına dikkat edilmeli, gözü yorması sebebiyle büyük harf kullanımı sınırlandırılmalı, hitap edilecek kitleye göre yazı puntosu ve satır aralığı belirlenmeli, kalın ve italik harfler yalnızca dikkat çekilmek istenen yerlerde kullanılmalıdır.

* Sayfa düzeninde dersin bir bütün olarak ele alınması, öğrencilerin ilgisini canlı tutmak için farklı görsellerin kullanılması, görsellerin net olması, beyaz arka plan üzerine siyah yazı tercih edilmesi, kullanılan tüm görsel ve yazılı ifadelerin sayfa üzerinde bir denge içinde sunulması gerekmektedir.

* Ders kitaplarının tasarımı, yazı tipleri ve sayfa düzeni öğrencilerin ilgisini çekmede önem arz eder; bu nedenle kitapların tasarımı bu alanda uzman kişiler tarafından yapılmalıdır.

* Uzaktan dil öğretiminde kullanılan ders kitaplarının aynı zamanda teknolojik olanaklarla bütünleşmiş bir sistem geliştirmesi gereklidir. Diğer bir deyişle, etkileşimli bir öğretime firsat tanımalıdır. Karekod uygulaması ile ders sunumları, dinleme kayıtları, görsel materyaller, kelimelerin seslendirmeleri gibi birçok teknoloji tabanlı olanağa erişim sağlayarak öğretim uygulamalarını çeşitlendirmelidir. Günümüz teknolojisi buna elverişlidir, yapılması gereken, kitapların, "z-kitap" formatıyla bu teknoloji ile bütünleştirilmesidir.

\section{Araștırmanın Amacı ve Alt Problemler}

$\mathrm{Bu}$ araştırmanın amacı, uzaktan dil öğretiminde kullanılacak ders kitaplarının temel nitelikleri doğrultusunda Yeni İstanbul Uluslararası Öğrenciler İçin Türkçe Öğretim Setinin uzaktan eğitimde kullanıma uygun olup olmadığını incelemektir. Bu çalışma özellikle salgın nedeniyle zorunlu olarak uzaktan dil öğretimine başlayan kurumlar ve öğretmenler ile uzaktan eğitime uygun materyal geliştirme çabasında olan ders kitabı yazarları için, uzaktan eğitimde kullanılacak z-kitapların taşıması gereken özellikleri belirlemesi noktasında önem taşımaktadır. Bu çalışmada, belirtilen amaç çerçevesinde aşağıdaki alt problemlere yanıt aranmıştır:

1. Yeni İstanbul Uluslararası Öğrenciler İçin Türkçe Öğretim Seti, uzaktan eğitimde kullanım için ne tür teknolojik alt yapıya sahiptir? 
2. Yeni İstanbul Uluslararası Öğrenciler İçin Türkçe Öğretim Seti, biçimsel açıdan uzaktan eğitimde kullanıma uygun mudur?

3. Yeni İstanbul Uluslararası Öğrenciler İçin Türkçe Öğretim Seti, içerik açısından uzaktan eğitimde kullanıma uygun mudur?

\section{Yöntem}

\section{Araștırma Modeli}

$\mathrm{Bu}$ çalışmada nitel araştırma tekniklerinden doküman analizi kullanılmıştır. Doküman analizi, araştırılması hedeflenen, olay veya olgular hakkında bilgi içeren yazılı materyallerin analiz edilmesidir. Doküman analizi, belli bir amaca uygun olarak dokümanlara ulaşma, orijinal olup olmadığını kontrol etme, dokümanları anlama, veriyi analiz etme, veriyi kullanma aşamalarından oluşmaktadır (Yıldırım ve Şimşek, 2008, 43). Bu araştırmada 2020 yılında Kültür Sanat Basımevi tarafından yayınlanmış "Yeni İstanbul Uluslararası Öğrenciler İçin Türkçe Öğretim Seti” uzaktan eğitimde kullanılmaya uygunluk bağlamında incelenmiştir.

\section{Verilerin Kaynağı}

Yetişkinlere yabancı dil olarak Türkçe öğretiminde kullanılan çeşitli öğretim setleri bulunmaktadır. Uzaktan öğretimde kullanılabilecek dijital alt yapıya sahip olması ve gerek yurt dışında gerekse Türkiye'de çok sayıda kurum tarafından tercih edilen bilinen bir set olması sebebiyle Yeni İstanbul Uluslararası Öğrenciler İçin Türkçe Öğretim Seti örneklem olarak seçilmiştir. A1, A2, B1, B2 ve C1 olmak üzere beş dil seviyesi için tasarlanmış olan bu öğretim seti, uzaktan eğitimde kullanıma uygunluk bakımından değerlendirilmiştir.

\section{Verilerin Toplanması ve Analizi}

Araştırmanın verileri Yeni İstanbul Uluslararası Öğrenciler İçin Türkçe Öğretim Setinin doküman analizi tekniğiyle incelenmesiyle toplanmıştır. Belirtilen öğretim setinin uzaktan eğitimde kullanımının uygunluğunun irdelendiği çalışmada, verilerin çözümlenmesinde alanyazından derlediğimiz çalışmalardan (Başal, 2013; Bozkurt ve Bozkaya, 2015; Diaz, 2003; Kaya, 2002; Weimin ve Dhanarajan, 1999; Yalman ve Başaran, 2018) ve kendi öğretim deneyimlerimizden hareketle saptadığımz şu ölçütler göz önünde bulundurulmuştur:

1. Teknolojik uygunluk:

a. Etkileşimli öğrenmeye firsat tanıyıp tanımadi $\breve{g l}$,

b. Öğrencilerin bireysel çalışmalarını ögretmenlerin denetleme imkânının olup olmadı̆̆g,

c. Kitapların bireysel çalışmalarda ve canlı derslerde kullanım kolaylığı sağlayan akıllı kitap özelliğinin bulunup bulunmadı̆ğ.

2. Biçimsel uygunluk:

a. Bölüm numarasının ve adının yazıldı ğ bir kısım olup olmadiğl,

b. Her ünitenin başında dersin hedeflerinin belirtilip belirtilmediği,

c. İçindekiler bölümünün olup olmadı̆̆g,

ç. Kitapların tasarımının hitap ettiği kitleye uygun olup olmadı $\breve{g}$,

d. Kitaplardaki resim, şekil, grafik, sembol ve tablolar gibi görsel unsurların uygun kullanilıp kullanılmadiğl,

e. Kitaplardaki satır aralığı, yazı puntosu, kalın-italik yazı kullanımı gibi okumayı kolaylaştırıcı unsurların uygun kullanılıp kullanılmadı̆̆l, 
f. Kitaplardaki sayfa düzeninin ve görsellerin uygun olup olmadı ̆̆

3. İçeriksel uygunluk:

a. Öğrencilerin yapacakları etkinlikleri açılklayan yönergelerin olup olmadı̆̆g,

b. Verilen konunun pekiştirilmesini sağlayacak alıştırmaların olup olmadı̆̆

c. Kazanımların ne ölçüde gerçekleştiğini kontrol amaçlı değerlendirme sorularının olup olmadı $\breve{g l}$,

ç. Metinlerin öğrenci düzeyine ve ön öğrenmelerine uygun olup olmadı̆̆

d. Kitapların dilin içinde geliştiği kültürün de öğretimine hizmet edip etmediği.

\section{Bulgular}

Bu bölümde, Yeni İstanbul Uluslararası Öğrenciler İçin Türkçe Öğretim Setinin uzaktan eğitimde kullanımına uygunluk bakımından incelenmesi sonucu elde edilen bulgular sunulmuştur.

Araştırmanın birinci alt problemi "Yeni İstanbul Uluslararası Öğrenciler İçin Türkçe Öğretim Seti, uzaktan eğitimde kullanım için ne tür teknolojik alt yapıya sahiptir?" biçiminde belirlenmişti. Bu alt probleme ilişkin bulgular aşağıda yer almaktadır:

Yeni İstanbul Uluslararası Öğrenciler İçin Türkçe Öğretim Seti, "kişiselleştirilmiş zenginleştirilmiş etkileşimli” bir kitaptır. Bu öğretim setini kullanan öğretmenler, sınıfındaki öğrencilerin hazırbulunuşluk durumuna göre kitaba eklemeler yapabilmekte, böylece sınıfındaki öğrencilerin durumuna göre kitabı kişiselleştirebilmektedir. Kitaptaki öğrenme üniteleri video ve ses dosyaları desteğiyle zenginleştirilmiştir ve kitapta sunulan cevap anahtarı sayesinde öğrenci kendi öğrenme durumunu değerlendirebilmektedir. Kitabın z-kitap özelliği sayesinde uluslararası öğrenciler, kendi ülkelerinden tıpkı sınıf ortamındaki gibi etkileşimli olarak Türkçe öğrenme firsatını yakalayabilmektedirler.

İstanbul Uluslararası Öğrenciler İçin Türkçe Öğretim Seti, öğrencilerin kendi kendilerine çalışmaları sırasında doğru cevapları öğrenmeleri, bir soruyla ilgili tüm alternatif cevapları görmeleri, her ortamda karekodlar vasıtasıyla dinleme ve izleme kayıtlarına ulaşabilmeleri gibi özellikler sayesinde etkileşimli öğrenmeye firsat tanımaktadır. Dinleme ve izleme etkinlikleri için karekod kullanımı, öğrencilerin her ortamda öğrenme faaliyetlerini sürdürmelerini sağlamakta, öğrencileri sadece bilgisayar bulunan ortamlarla sınırlandırmamaktadır.

Çalışma kitabının etkileşimli hâle getirilmiş web tabanlı uygulaması üzerinden öğrenciler çalışmalarını çevrim içi ortamda yapabilmekte ve anlık geribildirimler sayesinde hatalarını fark ederek doğru yanıta ulaşabilmektedirler. Bu sayede öğretmen ile eş zamanlı olarak ekran başında olmasalar bile öğrenme faaliyetlerini sürdürebilmektedirler. Diğer taraftan öğretmenler ise öğrencilerin çalışmalarını sistem üzerinden takip edip ölçme değerlendirme bağlamında bunları değerlendirebilmektedir.

Kitapların bireysel çalışmalarda ve canlı derslerde kullanım kolaylığı sağlayan akıllı kitap özelliği bulunmaktadır. Ekrana yansıtılabilen ara yüz ile sayfalar arası hızlı geçiş yapılabilmekte, sayfa yakınlaştırma, sayfa üzerine çizim yapma, şekiller çizme, silme, metin ekleme gibi temel özellikler sayesinde öğretmenlere sınıf ortamında tahta başında ders anlatıyormuş gibi kolaylık sağlamaktadır. Ayrıca, kitap yazarlarınca kitapların içeriğinde yapılan değişikliklere ve güncellemelere kitabı kullanan kişiler anlık olarak ulaşabilmektedir. $\mathrm{Bu}$ sayede kitabın farklı basımlarına sahip olan öğrenciler ve öğretmenler, aynı kitap üzerinden çalışma olanağına sahip olmakta, kitabın son baskısını alma zorunluluğu bulunmamaktadır. Kullanıcılar, bilgisayarlarına kuracakları bir program yardımıyla kolaylıkla kitaplara ve her türlü güncellemelere ulaşma ve kitaba etkileşimli etkinlikler ekleme imkânına sahiptirler. Bu özellikleri sayesinde incelenen 
öğretim setinin, uzaktan dil öğretiminin ihtiyaçlarını karşılayacak teknik alt yapıya sahip olduğu söylenebilir.

Araştırmanın ikinci alt problemi "Yeni İstanbul Uluslararası Öğrenciler İçin Türkçe Öğretim Seti, biçimsel açıdan uzaktan eğitimde kullanıma uygun mudur?" biçiminde belirlenmişti. $\mathrm{Bu}$ alt probleme ilişkin bulgular aşağıda yer almaktadır:

Yeni İstanbul Uluslararası Öğrenciler İçin Türkçe Öğretim Seti A1, A2, B1, B2 ve C1 seviyelerinde olmak üzere ders kitabı, çalışma kitabı ve z-kitap için şifre ilekarekodlardan oluşmaktadır. Kitaplar biçimsel özellikleri açısından incelendiğinde, kitapların her birinin altı üniteden oluştuğu ve ünitelerde üzerinde durulacak konular ile geliştirilmesi beklenen dil becerilerinde yapılacak etkinliklerin açıklandığı "İçindekiler" bölümünün yer aldığ 1 görülmektedir. Üniteler ise altı konu alanını içinde barındıran üçer bölümden oluşmaktadır. Her bölümün adı ve numarasına sayfaların sağ üst köşesinde yer verilmiştir. Bununla birlikte her ünitenin ilk sayfasında o üniteye ait hedefler bulunmaktadır.

İnceleme sonucunda belirtilen öğretim setinde beceri alanlarındaki temalara uygun olarak öğrencilerin metinleri anlamalarını kolaylaştırmak amacıyla görsellere yer verilmiştir. Öğretim seti, Türkçe öğrenen yetişkinler için hazırlandığından, görseller yetişkin kitlesine uygun olarak seçilmiştir. Dil bilgisi bölümlerinde, hedeflenen dil yapısının özet biçiminde sunulduğu tablolara yer verilmiştir. Ayrıca anlatılan dil bilgisi yapısıyla ilgili istisnalar ve önemli kurallar da tablolaştırılarak sunulmuştur.

Kitaplar 11 punto ile yazılmış, A1 ve A2 düzeylerindeki kitaplarda satır aralığ daha geniş tutularak daha fazla görsele yer verilmiştir. İlerleyen düzeylerde ise metinlerin uzunluğu arttıkça görsellerin boyutu kü̧̈ültülmüştür. Metinlerde öğrencinin bilmediği düşünülen ve tema bağlamında özellikle öğrenmesi istenilen sözcük ve sözcük grupları koyu harflerle; terimler ise italik olarak yazılmıştır.

Araştırmanın üçüncü alt problemi "Yeni İstanbul Uluslararası Öğrenciler İçin Türkçe Öğretim Seti, içerik açısından uzaktan eğitimde kullanıma uygun mudur?" biçiminde belirlenmişti. Bu alt probleme ilişkin bulgular aşağıda yer almaktadır:

Belirli bir tema etrafında oluşturulan her ünitede, hedeflenen kazanımlara yönelik okuma, dinleme, yazma ve konuşma becerileri bulunmaktadır. Buna ek olarak, öğrencinin, ünite içerisinde neler ile karışılacağını göstermek için "Hazırlık Çalışması" ve ayrı bir başlık altında "Dil Bilgisi" bölümü yer almaktadır. Belirtilen bu çerçeve, her ünitede takip edilmiştir. Ünitelerde bulunan okuma, dinleme, yazma, konuşma ve dil bilgisi etkinliklerinin tümünde, öğrencinin görevini belirten açık ve net yönergeler vardır. Öğrencinin başka bir açıklamaya ihtiyaç duymadan sadece bu yönergeler ile etkinlikleri gerçekleştirme olanağı bulunmaktadır. Bu bakımdan kitabın web tabanlı uygulamasındaki etkinliklerin, bir rehbere ihtiyaç duyulmadan yapılabilmesi mümkündür.

Yeni İstanbul Uluslararası Öğrenciler İçin Türkçe Öğretim Seti, yapılandırmacı yaklaşım ile hazırlandığı için, dil bilgisi konularını sezdirerek öğretme amacı taşımaktadır. Bu nedenle, hiçbir ünite dil bilgisi konusu ile başlamamaktadır. Öncesinde öğretilmesi hedeflenen yapılar; hazırlık çalışmaları, okuma ve dinleme metinleri ile gösterilip sonrasında dil bilgisi açıklamaları verilmektedir. Öğrenci, her beceri alanındaki etkinlikler ile verilen konuya sürekli maruz kalmakta ve Türkçenin dilsel edinciyle birlikte iletişimsel edinci de gerçekleştirilmeye çalışılmaktadır.

Yeni İstanbul Uluslararası Öğrenciler için Türkçe Öğretim Seti, her ünitenin sonunda bulunan "Neler Öğrendik?" bölümü ile kazanımların ne ölçüde gerçekleştiğini kontrol edebilme olanağ 1 sunmaktadır. Hem örgün öğretimde hem de uzaktan öğretimde, öğrencinin öz değerlendirme yapmasına imkân tanımaktadır. Gerek kitap üzerinde bulunan etkinlikler gerekse etkileşimli kitap olma özelliği sayesinde kare kod okutarak ulaşılan web tabanlı uygulamasındaki etkinlikler ile zengin içeriklere ulaşmak mümkündür. Video destekli "İzle-Öğren”, ünite içerisinde 
ele alınan konularla ilişkili olarak sunulan "Günlük İfadeler”, öğrencinin verilen görev kapsamında video çekip uygulamaya yükleyebileceği "Kendini Çek", konuşma becerisine yönelik "Mikrofon Sende", ünite içerisinde verilen konuyu pekiştirmek amaçlı "Bir Adım Ötesi" ve genel değerlendirmenin yapıldığı "Neler Öğrendik" etkinlikleri ile öz değerlendirme yapılmasına olanak sağlayan çalışmalara yer verilmiştir. Burada asıl önemli olan, öğrencilerin tüm bu çalışmalara, web tabanlı uygulama üzerinden ulaşıp bir öğretmene ihtiyaç duymadan etkinlikleri gerçekleştirme ve doğru ile yanlışı görebilme imkânına sahip olmalarıdır.

İstanbul Uluslararası Öğrenciler İçin Türkçe Öğretim Setinde yer alan metinler incelendiğinde, kullanılan metinlerin, söylemsel, işlevsel ve tasarımsal yetinin geliştirilmesini amaçladığını söylemek mümkündür. Metin çalışmaları, söylem boyutunda ele alınmış ve iletişimsel yaklaşım açısından öğrencinin günlük yaşamında karşılaşabileceği türden konulara yer verilmiştir. Ayrıca, amaca yönelik metin türü seçimleri yapılmıştır. Bu sayede, öğrencinin metnin işlevselliği yönünü de kavraması hedeflenmiştir. Ek olarak, iletiler, konuşma düzleminde etkileşimsel olarak sıralanmış ve bu sayede öğrencinin metnin tasarımına dair kazanımları elde etmesi amaçlanmıştır. Buradan hareketle, metinlerin, dil kullanımına yönelik olduğunu ve öğrenciyi dili kullanarak öğrenme sürecine soktuğunu söylemek mümkündür. Metinlerin içeriği kadar öğrenci düzeyine uygunluğu da çok önemlidir. Yabanc1lara Türkçe öğreten kitaplardaki metinlerin dilsel, sosyodilbilimsel ve edimsel yönden seviyeye ve hedef kazanımlara uygun olması gereklidir. İstanbul Uluslararası Öğrenciler İçin Türkçe Öğretim Seti, bu açıdan ele alındığında, metinlerin sözcük seçimi, dil bilgisi, söz dizimi ve anlam bilgisi yönünden öğrenci düzeyine uygun ve ön öğrenmeye elverişli olduğu söylenebilir. Metinlerde ayrıca, selamlama, nezaket kuralları, deyim ve atasözleri gibi sosyodilbilimsel ögelere ve söz eylemlere düzey ve hedef kazanımlar gözetilerek yer verildiği görülmüştür. Kitaplar incelendiğinde, okuma metinlerinin genellikle diğer etkinliklerden önce verildiği belirlenmiştir. Ünite içerisinde ele alınan içeriğin okuma metinlerinde belli ölçülerde geçirilmesi iki bakımdan önemlidir: Birincisi, bu yolla metinlerin seviyeye uygun olmas1 sağlanmaktadır çünkü ünitede verilecek konu ve yapılar Avrupa Dilleri Ortak Başvuru Metninde Council of Europe, 2018) belirlenen ölçütler doğrultusunda metinlerde yer almaktadır. Bu durum, metin yazarlarını sınırlayan ve o düzeydeki dil kullanımının gereklilikleri içerisinde kalmalarını sağlayan bir unsur olarak karşımıza çıkmaktadır. İkincisi, öğrencilerin ön öğrenmelerine katk1 sunmaktadır. Metin içerisinde geçen yeni yapılar, öğrenciyi hem içeriğe hazırlamakta hem de öğrencinin öğreneceği yapıyı bir söylem içerisinde görmesine olanak tanımaktadır.

Dil, içinde yaşadığı kültür ile gelişir ve aynı zamanda o kültürü aktarır. Dolayısıyla, yabancı dil öğretiminde kültürel unsurların aktarılması, dilin iletişimsel edincinin kazanılması noktasında oldukça önemlidir. İstanbul Uluslararası Öğrenciler İçin Türkçe Öğretim Setinde yer alan metinler, seviyelere göre oransal farklılık gösterse de kültür aktarımına hizmet edecek şekilde planlanmıştır. Metinlerde, amaca uygunluk, bilgisellik ve metinlerarasılık ilkelerinin uygulanmasıyla kültürel ögeler aktarılmaya çalışılmıştır. Bu noktada sadece Türk kültürüne ait unsurlara değil; diğer kültürlere ait değerlere de yer verilerek öğrencilerin kendi kültürleriyle diğer kültürleri karşılaştırmalarına da zemin hazırlanmıştır. Kitaplardaki kültür ile ilgili ögeler şu şekilde sınıflandırılabilir: Günlük yaşam ile ilgili kültürel ögeler, kişiler arası ilişkiler ile ilgili kültürel ögeler, değerler ve eğitim ile ilgili kültürel ögeler, edebiyat-sanat ve müzik ile ilgili kültürel ögeler, gelenekler ve folklor ile ilgili kültürel ögeler, sosyal yaşam, coğrafya ve mekân ile ilgili kültürel ögeler. Gerek tema düzeyinde, gerek metin içeriklerinde gerekse etkinlik örnekleri ile belirtilen kültürel ögeler sunulmaya çalışılmıştır. Bu bakımdan, İstanbul Uluslararası Öğrenciler İçin Türkçe Öğretim Setinin Türk dili ile beraber Türk kültürünü de öğretmeyi hedeflediğini söylemek mümkündür. 


\section{Sonuç, Tartışma ve Öneriler}

Araştırmada "Yeni İstanbul Uluslararası Öğrenciler İçin Türkçe Öğretim Seti” uzaktan eğitimde kullanıma uygunluğu bakımından incelenmiş ve bu yolla uzaktan dil öğretiminde kullanılacak ders kitaplarının temel nitelikleri belirlenmeye çalışılmıştır. Araştırma neticesinde ulaşılan sonuçlar şu şekildedir:

1. Uzaktan dil öğretiminde kullanılan materyaller de gelişen teknolojiyle beraber değişikliğe uğramıştır. Teknoloji destekli materyaller öğrencilerin öğrenme motivasyonlarını, derse etkin katılımını, öğrenme hızlarını ve başarılarını etkilemektedir (Altunbay ve Bıçak, 2018; Başal, 2011; Dargut ve Çelik, 2014; Karadüz ve Baytak, 2010; Yürektürk ve Coşkun, 2020). Ders materyallerinin çağın teknolojik gereklerini yerine getirebilmesi için, teknolojik alt yapısı ile etkileşimli öğrenme ortamı sağlayarak öğretim uygulamalarını çeşitlendirmesi gerekmektedir. Etkileşimli öğrenmenin öğrenci - öğrenci, öğrenci-öğretmen ve öğrenci-materyal etkileşimi olmak üzere üç şekilde ele alınması gerekmektedir ancak genellikle öğrencinin öğretim materyali ile olan etkileşimi geri planda kalmaktadır (Özkul ve Girginer, 2001). Bu araştırmada incelenen Yeni İstanbul Uluslararası Öğrenciler İçin Türkçe Öğretim Setinin; öğrencilerin hazırbulunuşluğuna göre kitaba ekleme ve çıkarmalar yapılabilme imkânı sunması, karekod özelliği ile zenginleştirilmiş dinleme ve izleme girdileri sağlaması, cevap anahtarı ile öğrencilerin kendilerini değerlendirmelerine olanak tanıması ve z-kitap özelliği ile etkileşimli öğrenme ortamı oluşturması sebepleriyle uzaktan dil öğretiminde kullanım için gerekli teknolojik alt yapıya sahip olduğu görülmüştür. Ayrıca, öğrencilerin kitap yazarları tarafından kitapların içeriğinde yapılan değişikliklere ve güncellemelere anlık olarak ulaşabilmeleri teknolojik olanaklar ile bütünleşmiş bir sistem geliştirildiğini ortaya koymaktadır. Uzaktan eğitimde kullanılan ders kitapları, öğrencilerin bireysel öğrenmelerine olanak sağlayacak şekilde tasarlanmalıdır. Yeni İstanbul Uluslararası Öğrenciler İçin Türkçe Öğretim Seti, z-kitap ve akıllı kitap özellikleri taşımasından ötürü, öğrencilerin anlık geri bildirimler alarak hatalarını fark edip doğru cevaplara ulaşmasını sağlaması ile öğrencilerin bireysel öğrenmelerine olanak tanımaktadır.

2. Bu alanda yapılan çalışmalar (Kaya, 2002; Mayer, 2009; Rowntree, 1994) uzaktan öğretimde kullanılacak ders kitaplarında öğrencilerin kitabı bir bütün olarak algılamalarını sağlayacak ayrıntılı içindekiler bölümü, her bölümün başında bölüm numaraları ve o bölümde gerçekleştirilmesi planlanan öğrenme hedeflerinin bulunması gerektiğine işaret etmektedir. Yeni İstanbul Uluslararası Öğrenciler İçin Türkçe Öğretim Setinde yer alan her kitapta ünitelerdeki okuma, dinleme, konuşma, yazma ve dil bilgisi becerilerinin detaylı olarak gösterildiği içindekiler bölümü, her ünitenin başında ünite numarası ve o ünitenin kazanımları ile konularının sunulduğu giriş sayfası bulunması, öğrencilerin kitaplara bir sistem çerçevesinde yaklaşmalarını sağlamakta, kitapların bu yönüyle uzaktan öğretimde kullanılmaya biçimsel açıdan uygun olduğu görülmektedir. Bununla birlikte uzaktan eğitimde kullanılan ders kitaplarının tasarımının ve kitaplarda yer alan görsellerin öğrenci seviyesine uygun olması önem arz etmektedir. Bodur (2016), uzaktan eğitimde kullanılan grafik, tablo, şema, harita, resim, fotoğraf ve karikatür gibi görsellerin öğrencilerin ilgilerini çekerek güdülenmelerini sağladığını, zor anlaşılan konuların anlaşılmasını kolaylaştırdığını ve içeriğin zenginleşmesine yardımcı olduğunu belirtir. İncelenen sette görsellerin, öğrencilerin seviyelerine uygun olduğu ve öğrencilerin gerek metinleri gerekse yeni bilgileri anlamalarına yardımcı olduğu görülmektedir. Yetişkinler için hazırlanan ders kitaplarında puntonun 9-12 arasında olması uygun bulunmaktadır (Alpan Bangir, 2008). İncelenen set, punto büyüklüğünün 11 olması özelliğiyle de hitap ettiği kitleye uygundur. Uzaktan eğitim için hazırlanan bu öğretim setinde yalnızca punto değil; satır aralığı, metinlerin uzunluğu ve görsellerin miktarı da hitap edilen kitleye göre düzenlenmiştir. Kaya (2002), uzaktan eğitim için hazırlanan ders kitaplarında öğrencilerin dikkatinin çekilmesi gereken bölümlerde italik ve koyu harf kullanımının gerektiğini belirtmiştir. Ele alınan uzaktan öğretim materyali, kelime öğretimi, yeni bilgi aktarımı ve terimlerin yazımı esnasında italik ve koyu harf kullanımına yer vermiştir. 
3. Uzaktan öğretimde, özellikle çevrimiçi ders olanağı bulunmayan durumlarda, öğretim sürecinin sorumluluğu büyük ölçüde materyalin üzerindedir. Uzaktan eğitimde kullanılacak materyallerin öğrencinin kendi kendine öğrenmesine olanak sağlayacak şekilde tasarlanmas1 gerekmektedir (Duffy ve Kirkley, 2004). Bu sayede öğrenci, çevrimiçi ders alabilme imkânı olmasa bile dil öğrenme firsatı yakalamış olacaktır. İncelenen öğretim setinde, her etkinlikten önce o etkinliğin nasıl gerçekleşritileceğini açıklayan, öğrencinin dil düzeyine uygun yönergelerin bulunması, etkinliğe ait olası cevapların etkinlik sonunda görülebilme olanağının olması, öğrencinin hangi bölümde kaç etkinliği doğru kaçını yanlış yaptığını gösteren bir değerlendirme sisteminin bulunması gibi özellikler, öğrencinin kendi kendine çalışabilmesine imkân sağlamaktadır. Ayrıca düzenli bir kursa devam edenler için de öğrencilerin tüm çalışmalarının ders öğretmeni tarafından kontrol edebileceği bir arayüzün bulunması, hem örencilerin hangi konularda eksikliklerinin olduğunu öğretmenin görmesine hem de öğretmenlerin öğrenci performanslarını değerlendirmesine olanak tanımaktadır.

Dil öğrenirken kişinin kendi kendini değerlendirmesi, öğretmen ya da akran değerlendirmesi kadar önemlidir (Council of Europe, 2018; Mirici ve Kavakl1, 2017; Sadler, 2006). Öğrenci kendi öğrenme sürecinin farkına vardığında ve eksik olan yönlerini gördüğünde, çalışma esnasında nelere odaklanacağına karar vermesi kolaylaşacaktır. İncelenen öğretim setinde her ünitenin sonunda bulunan "Neler Öğrendik?" bölümü, öğrencinin o ünitedeki eksiklerini görerek ilgili bölümü tekrar etmesine olanak tanımaktadır. Ayrıca her ünite sonunda yer alan "Öz Değerlendirme" bölümünde öğrenciler, Avrupa Dilleri Ortak Başvuru Metninde (Council of Europe, 2018) yer alan kazanımlara ne kadar ulaştıklarını kendileri değerlendirmektedirler.

Türkçe öğretiminde amaç, doğru ve etkili iletişim becerisi kazandırmak olmalıdır. $\mathrm{Bu}$ nedenle, yalnızca dil edincini değil; iletişimsel edinci de geliştirmeye yönelik, dili hem yapısal hem anlamsal hem de kullanımsal boyutlarıyla ele alan planlamalar, düzenlemeler ve çalışmalar yapılmalıdır (Başkan, 2006; Brown, 2014; Demircan, 2013; Demirel; 2010; Krashen, 1982; LarsenFreeman, 2001). Yeni İstanbul Uluslararası Öğretim Seti bu açıdan incelendiğinde, kitaplarda dil bilgisi öğretiminin biçim-anlam ve kullanım boyutuyla birlikte gerçekleştirildiği görülmektedir. Bir dil yapısı verilirken o biçimbirimin kullanımı metin içinde gösterilmiş, ardından o biçimbirimin diğer anlamları ve biçimsel özellikleri üzerinde durulmuştur. Konuşma ve yazma etkinlikleri de öğrencilerin yeni öğrendikleri biçimbirimleri kullanmalarına olanak sağlayacak şekilde belirlenmiştir.

Uzaktan eğitimde kullanılmak üzere materyal hazırlayacak araştırmacılara şu önerilerde bulunulabilir:

1. Materyalin, örgün öğretimin yanında, kendi kendine Türkçe öğrenecek öğrenciler de göz önünde bulundurularak hazırlanması gerekmektedir. Bu nedenle,

- öğrenciyi yönlendirici yönergeler net ve anlaşılır olmalıdır.

- öğrencinin çalışmalarını kontrol edebileceği cevap anahtarı bulunmalıdır.

- gramer anlatımı öğrencinin anlayabileceği netlikte yapılmalıdır. Eğer imkân varsa, Türkçenin yanında yaygın bir yabancı dilde de dil bilgisi açıklamalarına yer verilebilir. $\mathrm{Bu}$, Türkçeyi başka bir dil üzerinden öğretme anlamına gelmez, sadece kendi kendine öğrenen öğrencilere kolaylık sağlar.

- materyallerin tasarımı, sayfa düzeni, kullanılan görseller, tablolar, şekiller gibi biçimsel unsurlar, öğrencinin konuyu kendi kendine öğrenmesini kolaylaştıracak şekilde düzenlenmelidir.

2. Materyaller, öğrencinin herhangi bir mekâna bağımlı kalmadan öğrenme faaliyetlerini sürdüreceği biçimde hazırlanmalı ve etkileşimli öğrenmeye firsat tanımalıdır. Karekod uygulaması ile ders sunumlarına, dinleme kayıtlarına, görsel materyallere, kelimelerin telaffuzlarına erişim sağlayarak esnek bir öğrenme ortamı oluşturmalıdır. 
3. Materyallerde, öğrenme kazanımların ne ölçüde gerçekleştiğini kontrol amaçlı değerlendirme bölümü yer almalıdır. Ayrıca konular öğrencilerin düzeylerine ve ön öğrenmelerine uygun olarak sunulmalidır.

\section{Kaynakça}

Adıyaman, Z. (2002). Uzaktan eğitim yoluyla yabancı dil öğretimi. TheTurkish Online Journal of EducationalTechnology, 1(1), 92-97.

Al, U. \& Madran, O. (2004). Web tabanlı uzaktan eğitim sistemleri: sahip olması gereken özellikler ve standartlar. Bilgi Dünyasl, 5(2): 259-271. https://doi.org/10.15612/BD.2004.491

Alpan, B. G. (2008). Ders kitaplarındaki metin tasarımı. Türk Eğitim Bilimleri Dergisi, 6(1), 107134.

Altıparmak, M., Kurt, İ.D. \& Kapıdere, M. (2011, Şubat 2-4). E-öğrenme ve uzaktan eğitimde açık kaynak kodlu ögrenme yönetim sistemleri. XIII. Akademik Bilişim Konferansı İnönü Üniversitesi. https://ab.org.tr/ab11/kitap/altiparmak_kurt_AB11.pdf

Altunbay, M.\& Bıçak, N. (2018). Türkçe eğitimi derslerinde "z kuşağı" bireylerine uygun teknoloji tabanlı uygulamaların kullanımı. ZeltschriftFürDıWWelt Der Türken, 10(1), 127-142.

Arar, A. (1999). Uzaktan eğitimin tarihsel gelişimi, uzaktan eğitim uygulama modelleri ve maliyetleri. 1. Uzaktan Ĕ̈itim Sempozyumu 15-16 Kasım 1999 Bildiri Kitabı (ss.2528).Kara Kuvvetleri Eğitim ve Doktrin Komutanlığı.

Arslan, M. (2011). Uzaktan eğitim. Ahmet Yesevi Üniversitesi Ulaknet 2011 Çalıştayı. https://www.slideshare.net/arcom2010/uzaktan-eitim-sunumu

Başal, A. (2013). E-öğrenmede yabancı dil dersine yönelik içerik geliştirme ve yazarlık araçları. V. Yüzer, G. Telli-Yamamoto\& U. Demiray (Editörler). Türkiye'de E-Öğrenme: Gelişmeler ve Uygulamalar IV (67-80). Anadolu Üniversitesi Yayınları.

Başkan, Ö. (2006). Yabancı dil ögretimi ilkeler ve çözümler. Multilingual Yabancı Dil Yayınları.

Birinci, F. G. (2020). Yabancı dil olarak Türkçe öğretiminde kullanılan bilişim teknolojileri üzerine bir inceleme. Sakarya UniversityJournal of Education, 10(2), 350-371. https://doi.org/10.19126/suje.685534

Bodur, F. (2016). Uzaktan öğretim ders kitaplarında kullanılan görsel öğelerin öğrenmeye etkileri: Anadolu Üniversitesi örneği. Ĕgitim ve Öğretim Araştırmaları Dergisi, 5(1), 70-80.

Bozkurt, A. (2017). Türkiye'de uzaktan eğitimin dünü, bugünü ve yarını. Açıköğretim Uygulamaları ve Araştırmaları Dergisi AUAd, 3(2), 85-124.

Bozkurt, A. \& Bozkaya, M. (2015). Evaluation criteria for interactive e-books for open and distance learning. International Review of Research in Open and Distributed Learning, 16(5): 58-82.

Brown, H. D. (2014). Principles of languagelearningandteaching. PearsonEducation.

Council of Europe (2018). Common European framework of reference for languages: Learning, teaching, assessment, companion volume with new descriptors. Strasbourg Cedex.

Dargut, T., \& Çelik, G. (2014). Türkçe öğretmeni adaylarının eğitimde teknoloji kullanımına ilişkin tutum ve düşünceleri. Ana Dili Ĕgitimi Dergisi, 2(2), 28-41.

Demircan, Ö.(2012). Yabancı dil öğretim yöntemleri. Der Yayınları.

Demirel, Ö. (2010). Yabancı dil ögretimi. Pegem Akademi Yayıncılık. 
Diaz, P. (2003). Usability of hypermedia educational e-books. D-Lib Magazine, 9(3), http://www.dlib.org/dlib/march03/diaz/03diaz.html

Duffy, T. M. \& Kirkley, J. R. (2004) Learner-centered theory and practice in distance education: Cases from higher education. Routledge.

Elitaş, T. (2017). Uzaktan eğitim lisans sürecinde yeni iletişim teknolojileri: Atatürk Üniversitesi Uzaktan Eğitim Merkezi [Yayımlanmamış doktora tezi]. Marmara Üniversitesi Sosyal Bilimler Enstitüsü.

Fidan, N. (2012). Okulda ögrenme ve ögretme. Pegem Akademi Yayıncılık.

Göker, M. (2019). Yabancı dil olarak Türkçenin öğretiminde uzaktan eğitim web sitelerinin kullanılabilirlik açısında incelenmesi. (Yayımlanmamış yüksek lisans tezi). Sakarya Üniversitesi Eğitim Bilimleri Enstitüsü.

Gülersoy, A. E. (2013). İdeal ders kitabı arayışında sosyal bilgiler ders kitaplarının bazı özellikler açısından incelenmesi. International Journal of New Trends in Arts, Sports and Science Education, 2(1), 8-26.

Husmann, D. E. \& Miller, M. T. (2001). Improving distance education: Perceptions of program administrators. The Online Journal of Distance Learning Administration, 4(3), 1-5.

İşman, A. (2008). Uzaktan eğitim. Pegem A Yayınları.

Jabeen, S.S. \& Thomas, A.J. (2015, October 21-23). Effectiveness of online language learning, Proceedings of the World Congress on Engineering and Computer Science. http://www.iaeng.org/publication/WCECS2015/WCECS2015_pp297-301.pdf

Jarvis, H. \& Krashen, S. (2014). Is CALL obsolete? Language acquisition and language learning revisited in a digital age. The Electronic Journalfor English as a Second Language, 17(4),1-6.

Kadızade, E. D. (2015). Yabancılara Türkçe öğretiminde akıllı telefon uygulamaları üzerine inceleme. Akademik Sosyal Araştırmalar Dergisi, 10, 742-752.

Karadüz, A. \& Baytak, A. (2010). Teknoloji destekli öğretimin Türkçe eğitimi bölümü öğrencileri tarafından nasıl algılandığının incelenmesi. Sakarya Üniversitesi Eğitim Fakültesi Dergisi, 20, 7-29.

Karasu, G. \& Sarı, Y.E. (2019). Uzaktan eğitim ve yabancı dil öğrenme özerkliği. Diyalog Interkulturelle Zeitschrift Für Germenistik, 7(2), 321-334.

Kaya, Z. (2002). Uzaktan eğitim. Pegem A Yayınları.

Keegan, D. J. (1980). On defining distance education. Distance Education, 1(1), 13-36.

Kılıç, A. \& Seven S. (2002). Konu alanı ders kitabı incelemesi. Pegem A Yayıncılık.

Kırık, A. (2014). Uzaktan eğitimin tarihsel gelişimi ve Türkiye'deki durumu. Marmara İletişim Dergisi, 21, 73-94. https://dx.doi.org/10.17829/midr.20142110299

Krashen, S.D. (1982). Principles and practice in second language acquisition. Oxford University Press.

Küçükahmet, L. (2004). Öğretmenlik mesleğine giriş. Nobel Akademik Yayıncılık.

Larsen-Freeman, D. (2001). Teaching grammar. InM. Celce-Murcia (Ed.) Teaching English as a Second orForeign Language (251-266). Heinle\&Heinle.

Lease, A. J. \& Brown, T. A. (2009). Distance learning: Past, present and future. International Journal of Instructional Media, 36(4), 415-426. 
Mayer, R. E. (2009). Multimedia learning. Cambridge Press.

MEB (2019). Türkçe dersi öğretim programı. Millî Eğitim Bakanlığı.

Mirici, İ. H. \& Kavakl1, N. (2017). Teaching the CEFR oriented practices effectively in the M.A. program of an ELT department in Turkey. International Online Journal of EducationandTeaching (IOJET), 4(1). 74-85.

Moore, M. G. \& Kearsley, I.G. (2012). Distance education: A systems view of online learning. Wadsworth Publishing.

Mutlu, E. \& Tuga, B.E. (2013). The role of computer-assisted language learning (CALL) in promoting learner autonomy. Eurasian Journal of Education Research, 51, 107-122.

Özarslan, Y. (2008, Aralık 22-23). Uzaktan eğitim uygulamaları için açık kaynak kodlu öğrenme yönetim sistemleri. XIII. Türkiye'de İnternet Konferans1, ODTÜ.http://inettr.org.tr/inetconf13/kitap/ozarslan_inet08.pdf

Özgöl, M., Sarıkaya, İ. \& Öztürk, M. (2017). Örgün eğitimde uzaktan eğitim uygulamalarına ilişkin öğrenci ve öğretim elemanı değerlendirmeleri.Yükseköğretim ve Bilim Dergisi 7(2), 294-304. http://dx.doi.org/10.5961/jhes.2017.208

Özkul A. E.\&Girginer, N. (2001). Uzaktan eğitimde teknoloji ve etkinlik. I. Uluslararası Eğitim Teknolojileri Sempozyumu Bildiriler Kitabı, Sakarya.

Özperçin A., Cihan N.\&Logie N., Vakur Ç. (2015). ISO 9126 değerlendirme modelinin AdaptFramework'e uygulanması. Ï̈. Eğitim Bilimleri Enstitüsü İstanbul Eğitimde Yenilikçilik Dergisi, 1, 9-23.

Pilancı, H. (2009). Uzaktan Türkçe öğrenen yabancıların Türkçeyi iletişim aracı olarak kullanabilme yeterlikleri. Dil ve Dilbilimi Çalışmaları Dergisi, 5(2), 49-61.

Pilancı, H. (2015). Web tabanlı uzaktan dil öğretimindeki gelişmeler ve yabancı dil olarak Türkçe öğretimi, International Journal of Languages' Education and Teaching, 3(3), 253-267.

Pilanc1, H., Saltık, O.\& Zenci, Z.Ç. (2020). Açık ve uzaktan yabancı dil olarak Türkçe öğreticileri için temel ilkeler. Uluslararası Beşeri İlimler ve Eğitim Dergisi, 6(14). 516-529.

Pilancı, H., Çalışkan, H., Aydın, C.H., Karadağ, N, Söker, N., Saltık, O.\& Kayabaş, K.B. (2015). Uzaktan Türkçe öğretim programı (Tsp): Hazırlık, uygulama, sorunlar ve çözümler. TurkishStudies, 10 (11), 1277-1296. http://dx.doi.org/10.7827/TurkishStudies.8583

Rowntree, D. (1994). Preparing materials for open, distance, and flexible learning: an action guide for teachers and trainers. KoganPage.

Sadler, P. M. (2006). The impact of self- and peer-grading on student learning. Educational Assessment, 11(1), 1-31.

Senemoğlu, N. (2018). Gelişim öğrenme ve öğretim: kuramdan uygulamaya. Anı Yayıncılık.

Seguin, R. (1989). The elaboration of school textbooks methodological guide. UNESCO.

Stickler, U., Hampel, R.\&Emke, M. (2020). A developmental framework for online language teaching skills, Australian Journal of Applied Linguistics, 3(1), 133-151. https://doi.org/10.29140/ajal.v3n1.271

Şen, Ü. (2016). Yabancı dil olarak Türkçe öğretiminde uzaktan eğitim programları. Ahi Evran Üniversitesi Kırşehir Eğitim Fakültesi Dergisi, 17(2), 411-428.

Taylor, J. (2001). Fifth generation distance education. e-Journal of Instructional Science and Technology, 4(1), 1-14. 
Verduin, J. R.\&Clark, J.T.A. (1994). Uzaktan eğitim: etkin uygulama esasları (Çeviren: İ. Maviş). Anadolu Üniversitesi Basımevi.

Wang, Y.\& Sun, C. (2001). Internet-based real-time language education: Towards a fourth generation distance education. CALICO Journal, 18(3), 539-561.

Wedemeyer, C. (1981). Learning at thebackdoor. University of Wisconsin Press.

Weimin, Y.\&Dhanarajan, G. (1999). Designing for open and distance learning materials. The Common wealth of Learning and Asian Development Bank.

Yalman, M., \& Başaran, B. (2018). Web 2.0 araçlarıyla geliştirilen uzaktan eğitim materyallerine yönelik eğitim fakültesi öğrencilerinin görüşleri. Online Academic Journal of Information Technology, 9(34), 81-95. https://dx.doi.org/10.5824/1309-1581.2018.4.006.x

Yaman, İ. (2015). Üniversitelerde zorunlu İngilizce (51) derslerinin uzaktan eğitim yoluyla verilmesinin art1 ve eksileri. TurkishStudies, 10(7), 967-984. http://dx.doi.org/10.7827/TurkishStudies.8108

Yavuz, M.,Hasançebi, M., \& Kurşun, E. (2020). Açık ve uzaktan öğrenme ders kitaplarında bulunması gereken özellikler: Sistematik literatür taraması. Pamukkale Üniversitesi Eğitim Fakültesi Dergisi, 50, 533-560. http://doi.org/10.9779/pauefd.728848

Yıldırım, A. \& Şimşek, H. (2008). Sosyal bilimlerde nitel araştırma yöntemleri. Seçkin Yayıncılık.

Yürektürk, F. N.\& Coşkun. H. (2020). Türkçe öğretmenlerinin teknoloji kullanımına ve teknoloji destekli Türkçe öğretiminin etkililiğine dair görüşler. Ana Dili Ĕgitimi Dergisi, 8(3), 9861000 .

Internet Kaynakları

http://aol.meb.gov.tr

http://yegitek.meb.gov.tr

https://cls.yale.edu/faculty/resources/online-teaching-tools-and-resources

https://ankuzef.ankara.edu.tr 